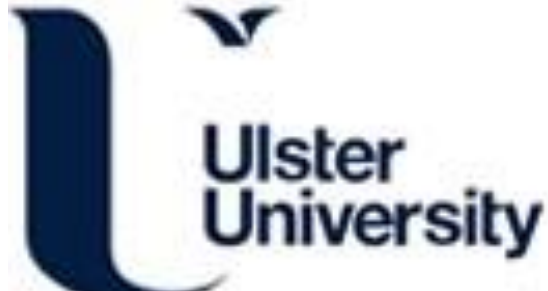

\section{Entrapment of Lactobacillus casei ATCC393 in the viscus matrix of Pistacia terebinthus resin for functional myzithra cheese manufacture}

Vasiliki, S., Terpou, A., Bosnea, L., Kanellaki, M., \& Singh - Nee Nigam, P. (2018). Entrapment of Lactobacillus casei ATCC393 in the viscus matrix of Pistacia terebinthus resin for functional myzithra cheese manufacture. LWT - Food Science and Technology, 89, 441-448. https://doi.org/10.1016/j.Iwt.2017.11.015

Link to publication record in Ulster University Research Portal

Published in:

LWT - Food Science and Technology

Publication Status:

Published (in print/issue): 01/03/2018

DOI:

10.1016/j.Iwt.2017.11.015

Document Version

Author Accepted version

\section{General rights}

Copyright for the publications made accessible via Ulster University's Research Portal is retained by the author(s) and / or other copyright owners and it is a condition of accessing these publications that users recognise and abide by the legal requirements associated with these rights.

\section{Take down policy}

The Research Portal is Ulster University's institutional repository that provides access to Ulster's research outputs. Every effort has been made to ensure that content in the Research Portal does not infringe any person's rights, or applicable UK laws. If you discover content in the Research Portal that you believe breaches copyright or violates any law, please contact pure-support@ulster.ac.uk. 


\section{Accepted Manuscript}

Entrapment of $L$. casei ATCC393 in the viscus matrix of Pistacia terebinthus resin for functional myzithra cheese manufacture

Vasiliki Schoina, Antonia Terpou, Loulouda Bosnea, Maria Kanellaki, Poonam S. Nigam

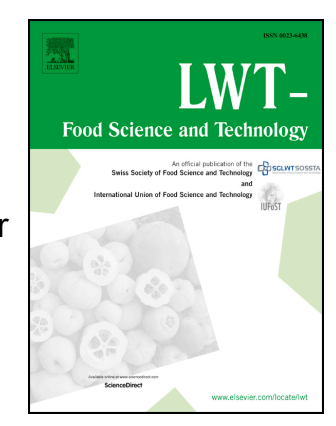

PII:

S0023-6438(17)30835-6

DOI:

10.1016/j.Iwt.2017.11.015

Reference: $\quad$ YFSTL 6644

To appear in: $\quad$ LWT - Food Science and Technology

Received Date: 19 June 2017

Revised Date: 6 November 2017

Accepted Date: 9 November 2017

Please cite this article as: Schoina, V., Terpou, A., Bosnea, L., Kanellaki, M., Nigam, P.S., Entrapment of $L$. casei ATCC393 in the viscus matrix of Pistacia terebinthus resin for functional myzithra cheese manufacture, LWT - Food Science and Technology (2017), doi: 10.1016/j.Iwt.2017.11.015.

This is a PDF file of an unedited manuscript that has been accepted for publication. As a service to our customers we are providing this early version of the manuscript. The manuscript will undergo copyediting, typesetting, and review of the resulting proof before it is published in its final form. Please note that during the production process errors may be discovered which could affect the content, and all legal disclaimers that apply to the journal pertain. 
$1 \quad$ Entrapment of L. casei ATCC393 in the viscus matrix of Pistacia terebinthus resin for functional myzithra cheese manufacture

4

5 Vasiliki Schoina ${ }^{1}$, Antonia Terpou ${ }^{1 *}$, Loulouda Bosnea ${ }^{1,2}$, Maria Kanellaki ${ }^{1}$, Poonam S.

6 Nigam $^{3}$.

7

8

9 1.Food Biotechnology Group, Department of Chemistry, University of Patras, GR-

10 26500, Patras, Greece.

11 2. National Agricultural Research Foundation, Dairy Research Institute, Katsikas,

1245221 Ioannina, Greece.

13 3. School of Biomedical Sciences, University of Ulster, Cromore Rd., Coleraine BT62

14 1SA, Northern Ireland, United Kingdom.

15

16

17

18

19

* Corresponding author

20

Dr. Antonia Terpou

21

E-mail : aterpou@upatras.gr

22

Tel.: +30-2610997123 


\section{Abstract}

24 Pissa Paphos, a natural mastic resin (Pistacia terebinthus) was evaluated as an 25 encapsulating and matrix-forming material for the immobilisation of the probiotic 26 bacterium Lactobacillus casei ATCC 393. The immobilized biocatalyst was added as an adjunct for the production of functional myzithra cheese. In total, four myzithra cheeses were manufactured: a. cheese with $L$. casei cells entrapped in a P. terebinthus matrix (Pissa Paphos) b. cheese with free L. casei cells and P. terebinthus resin, c. myzithra cheese with free $L$. casei cells without the resin and d. traditional myzithra cheese. P. terebinthus resin provided antimicrobial properties by suppressing the growth of fungi/yeasts in myzithra cheese during refrigerated storage. On the contrary, the presence of the resin did not affect the cell counts of the probiotic microorganism

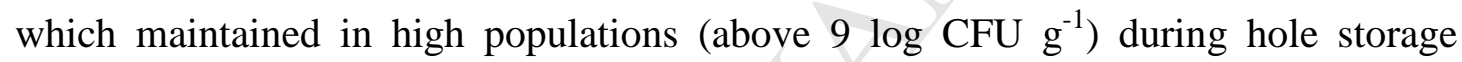
period. Additionally, the viscus matrix of the resin seems to confer a protective effect on entrapped L. casei cells since higher populations were observed over free cells. Moreover, all myzithra cheeses with incorporated resin were characterized by an exceptional mastic gum aroma and pleasant coherent texture which indicates the product's high commercialization potential.

Keywords: Pistacia terebinthus resin; probiotics; encapsulation; terpenes; myzithra cheese.

Chemical compounds studied in this article: $\alpha$-pinen (PubChem CID: 6654), $\beta$ pinen (PubChem CID: 14896), $\alpha$-terpineol (PubChem CID: 442501), 4-terpineol (PubChem CID: 11230), eukalyptol (PubChem CID: 2758), terpinolene (PubChem CID: 11463), myrtenol (PubChem CID: 10582), pinocarveol (PubChem CID: 88297), 
48 3-carene (PubChem CID: 26049), o-cymene (PubChem CID: 10703), verbenol 49 (PubChem CID: 61126).

50 


\section{Introduction}

52 Resins are plant products that exude naturally (surface resins) or can be obtained by 53 incision or infection (internal resins). They are insoluble in water but soluble in 54 organic solvents (Dell \& McComb, 1979). The most popular resins origin from Pistacia plants (Pistacia lentiscus, Pistacia terebinthus) which native to the Mediterranean region from Morocco and Portugal to Greece, Turkey and Syria (Rauf et al., 2017). Most of the plant parts including fruits, fruit fatty oil and resin were used as food and traditional medicine in the region since ancient times (Lardos, 2006).

Pissa Paphos, the mastic gum obtained from Pistacia terebinthus L. (Anacardiaceae family) tree, grows mainly on dry rock slopes and hill sides or in pine forests of Cyprus especially in Paphos and Limassol district. The tree's aromatic resin, called by the locals "Paphos pissa" and/ or "pissa Pafitiki" has a significant contribution to the local economy (Lardos, 2006). Over the years, different parts of $P$. terebinthus tree have been reported to provide several ethnopharmacological utilizations such as an antiseptic, diuretic, anti-inflammatory, antipyretic, antibacterial and antiviral agent, for wound treatments , eczema, burns and stomach-aches (Rauf et al., 2017; Topçu et al., 2007).

Lately, consumers awareness has focused on safe and high-quality food products, leading the food companies and related industries to implement novel methods for the production of functional foods (Bogue, Collins, \& Troy, 2017). One major category of functional foods is probiotic dairy products. Probiotics are lactic acid bacteria that when presented as live microbial supplements can confer a beneficially affect to the host by improving its intestinal microbial balance (Fuller \& Gibson, 1998). It has been established that a minimum level of probiotic lactic acid bacteria $\left(10^{6} \sim 10^{7} \mathrm{CFU} \mathrm{\textrm {g } ^ { - 1 }}\right)$ contained viable in dairy products is necessary for 
76 improving human health (Shori, 2015). Thus, scientists have recently targeted on the development of novel methods that will enhance probiotic viability in dairy products like cell immobilisation, microencapsulation, addition of prebiotics, drying (freezedrying, spray-drying) etc. (Bosnea, Moschakis, Nigam, \& Biliaderis, 2017). Techniques like immobilisation and microencapsulation of probiotics, even though represent a great challenge, have been established in order to improve the survival of probiotic bacteria giving promising results since they increased survival rates and stability of probiotics during fermentation processing and storage (Champagne, Ross,

Saarela, Hansen, \& Charalampopoulos, 2011; Terpou, Bekatorou, Kanellaki, Koutinas, \& Nigam, 2017). Also, cell encapsulation in dairy fermentation is a rapidly expanding research area because of its attractive technical and economic advantages compared to the conventional free cell systems (Bosnea, Moschakis, et al., 2017; Morales \& Ruiz, 2016). In addition, synthetic chemical additives are used as preservatives (antimicrobials, antioxidants and anti-browning) to ensure the products self-life and

91 safety or as flavor enforcements for improvement of products characteristics 92 (Carocho, Barreiro, Morales, \& Ferreira, 2014). However, many studies have confirmed that the excessive consumption of synthetic food additives is related with gastrointestinal, respiratory, dermatological and neurological adverse reactions and as a result consumers avoid the consumption of such products (Caleja et al., 2016; Carocho et al., 2014). Therefore, an alternative solution for enhancement of self-life and safety of food products is the use of natural additives. Mastic gum and its essential oils are very promising food additives since numerous resent studies have

99 demonstrated its antimicrobial and flavoring effect (Aksoy, Duran, \& Koksal, 2006; 
101 mastic gum (Pistacia lentiscus) as immobilisation support has recently been proposed

102 by Morkhade (2017) as a successful microencapsulating and matrix-forming material 103 for sustained drug release..

104 Thus, the aim of the present study was to examine the capability of Pistacia 105 terebinthus resin as a probiotic microencapsulation matrix and its use as an adjunct 106 for functional myzithra cheese making. The main targets of the study were to 107 investigate Pistacia terebinthus resin as a natural encapsulation matrix for the 108 probiotic bacterial strain Lactobacillus casei ATCC 393 (Saxami et al., 2012) and the 109 effects on probiotic cell viability in myzithra cheeses during 30 days of storage $\left(4^{\circ} \mathrm{C}\right)$ 110 and product's shelf-life and finally the influence on the aromatic profile of the 111 produced myzithra cheeses. 


\section{2. Materials and methods}

1132.1 Pistacia terebinthus resin for probiotic cell encapsulation

114 The probiotic Gram $^{+}$Lactobacillus bacterial strain Lactobacillus casei ATCC 393

115 (DSMZ, Braunschweig, Germany) was used for the microencapsulation process. The

116 probiotic L. casei ATCC 393 was selected according to its in vitro and in vivo studies

117 of the microbial survival in GI tract, adhesion to the intestine and modulation of the 118 intestinal microflora in rats (Saxami et al., 2012).

119 L. casei cells were grown at $37^{\circ} \mathrm{C}$ in de Man-Rogosa-Sharpe (MRS) liquid 120 medium (LabM, UK) for 48-72 h. Wet biomass was harvested by centrifugation

121 (Sigma 3K12, Bioblock Scientific, France) at $5000 \mathrm{rpm}$ for $10 \mathrm{~min}$. The cultivated 122 wet biomass was introduced in MRS liquid medium along with small particles of 123 sterile freeze-dried Pistacia terebinthus resin (pissa Paphos'), as described previously 124 by Antonia Terpou et al. (2017). Freeze drying was important for immobilisation 125 performance since the structure opens and creates holes where the probiotic LAB cells 126 can be entrapped. The system was placed in an incubator at $37^{\circ} \mathrm{C}$ and agitated 127 periodically for immobilisation to be achieved (approximately 48h). When 128 immobilisation bioprocess was performed (glucose in the liquid culture was $<1 \mathrm{~g} / \mathrm{L}$ ), 129 the fermented liquid was decanted Pistacia terebinthus resin with immobilized 130 probiotic cells was washed twice with sterile Ringer's $1 / 4$ solution targeting the 131 removal of any free cells (Schoina et al., 2015). All media were autoclaved at $120^{\circ} \mathrm{C}$ 132 at $1-1.5$ atm for $15 \mathrm{~min}$ prior to use.

133

1342.2 Verification of encapsulation of probiotic cells by scanning electron microscopy 135 and microbiological analysis 
136 Pieces of Pistacia terebinthus resin (pissa Paphos) in comparison with pieces of the

137 encapsulated biocatalyst were coated with gold in a Balzers SCD 004 Sputter coater

138 (Bal-Tec, Schalksmühle, Germany) for $2 \mathrm{~min}$. The samples were examined in a JSM-

1396300 scanning electron microscope (JEOL, Tokyo, Japan), operated at an accelerating

140 voltage of $20 \mathrm{kV}$. Scanning electron micrographs were obtained in order to investigate

141 probiotic cell encapsulation in Pistacia terebinthus matrix.

142 The counts of the entrapped L. casei cells into a specific amount of the resins'

143 viscus matrix were determined. In particular, $1 \mathrm{~g}$ of encapsulated biocatalyst was

144 added to $9 \mathrm{~mL}$ of ringer solution followed by shaking in a homogenizer for $210 \mathrm{~s}$.

145 Existing probiotic colonies of the encapsulated biocatalyst were identified by

146 enumeration in MRS agar medium $\left(37^{\circ} \mathrm{C}, 48-72 \mathrm{~h}\right)$. To demonstrate the complete

147 detachment of encapsulated L. casei cells from the resins matrix, the first homogenate

148 solution is poured out and new ringers' solution is added. Subsequently, the mixture is

149 shaken in a homogenizer for $210 \mathrm{~s}$ and the resulting liquid is tested until no grow of $L$.

150 casei colonies is detected.

151

$152 \quad 2.3$ Myzithra cheese production

153 Myzithra is a traditional Greek whey cheese produced by heating cheese whey at 88-

$15492{ }^{\circ} \mathrm{C}$ under continuous stirring for $40-45 \mathrm{~min}$ in order to obtain the protein remaining

155 from cheese production (Litopoulou-Tzanetaki \& Tzanetakis, 2011).

156 Sweet cheese whey $(0.54 \%$ fat, $1.67 \%$ total protein, $5.35 \%$ lactose and $\mathrm{pH} 6.4)$

157 derived as an industrial by-product of Graviera hard cheese production (A.VI.GAL

158 SA-Achaia milk industry) (Bozoudi et al., 2016) was used for myzithra cheese

159 making as described previously by Litopoulou-Tzanetaki and Tzanetakis (2011) with

160 small modifications. Specifically, cheese whey was gradually heated under continuous 
161 stirring with a rate of $1,5^{\circ} \mathrm{C} / \mathrm{min}$ up to $75^{\circ} \mathrm{C}$ and when small curd particles of whey

162 proteins were formed, the temperature was increased to $90{ }^{\circ} \mathrm{C}$ with a rate of $1{ }^{\circ} \mathrm{C} / \mathrm{min}$

163 for $45 \mathrm{~min}$ in total. Acidification of whey to $\mathrm{pH} 5.2$ was performed by the addition of

$16410 \%$ lactic acid before heating (Pappas \& Voutsinas, 2009). A very thin layer of

165 coagulum was formed on the surface of the whey after $45 \mathrm{~min}$ of heating at $90{ }^{\circ} \mathrm{C}$ and

166 then stirring was reduced and finally stopped. The formed curd was transferred

167 gradually by a perforated ladle into a sterile perforated fabric and hung from a pole in

168 a ventilated room at room temperature $\left(18 \sim 22^{\circ} \mathrm{C}\right)$ for $3 \mathrm{~h}$ in order to drain.

169 The drained curd was divided equivalent particles and four types of myzithra

170 cheeses were prepared: (C) control myzithra cheese; (F) myzithra cheese with free

171 probiotic cells (ME) myzithra cheese with encapsulated probiotic cells and (MF)

172 myzithra cheese with Pistacia terebinthus resin and free probiotic cells. In the case of

173 myzithra cheeses produced by the adjunct probiotic culture, the curd was cooled after

174 heating at $37^{\circ} \mathrm{C}$ and homogenously $1 \mathrm{~g}$ of free L. casei cells (F) or $0.5 \mathrm{~g}$ of

175 encapsulated L. casei cells in P. terebinthus resin (ME) or 0.5g of P. terebinthus resin

176 with $1 \mathrm{~g}$ of free $L$. casei cells (MF) were added respectively per $100 \mathrm{~g}$ of cheese curd.

177 All myzithra cheeses were placed into different sterile paper containers and stored for

17830 days at $4^{\circ} \mathrm{C}$.

179

\subsection{Microbiological analysis of myzithra cheese}

181 Representative $10 \mathrm{~g}$ portions of myzithra cheese samples were obtained at various time

182 intervals $\left(1^{\text {st }}, 5^{\text {th }}, 7^{\text {th }}, 14^{\text {th }}, 30^{\text {th }}\right.$ storage day at $\left.4^{\circ} \mathrm{C}\right)$ and blended with $90 \mathrm{~mL}$ of sterile

183 trisodium citrate $(2 \% \mathrm{w} / \mathrm{v})$ solution and mixed in a stomacher (Bagmixer 400, Model

184 VW, Interscience). The solution was then subjected to serial dilutions of $9 \mathrm{~mL}$ of 185 Ringer solution $1 / 4$ strength. Enumeration of viable cell counts of total aerobic 
186 mesophilic bacteria, lactococci, lactobacilli, enterobacteria, coliforms, yeasts \& fungi

187 and staphylococci were performed in triplicate by pour plating $0.1 \mathrm{~mL}$ or $1 \mathrm{~mL}$ of

188 appropriate dilutions on the selective media for each species and according to

189 instructions of the manufacturer as described previously by A. Terpou et al. (2017).

190 Cell counts were expressed as log of mean colony-forming units.

191 For the enumeration of $L$. casei cells MRS-V agar (0.1\% vancomycin) was

192 prepared which according to Tharmaraj and Shah (2003) would disintegrate the

193 adjunct probiotic strain and L. bulgaricus ssp. delbrueckii cell counts. The growth

194 potential of L. bulgaricus was expected in higher number than any lactobacilli

195 naturally occurring microflora since the whey used as raw material for myzithra

196 cheese production was not sterilized and was obtained after Graviera cheese

197 manufacture. Nowadays, in industrial dairies, cheese milk is at first pasteurized and

198 then used with the addition of a starter mesophilic or thermophilic culture for Graviera

199 cheese manufacture (Litopoulou-Tzanetaki \& Tzanetakis, 2011). In this case Graviera

200 cheese was manufactured by the addition of yogurt culture (L. bulgaricus ssp.

201 delbrueckii and $S$. thermophilus) and rennet enzyme thus, the presence of $L$.

202 bulgaricus cells can be expected. Cell counts were expressed as \% of L. casei viability

203 during 30 days of refrigerated storage.

\subsection{Physicochemical analysis}

206 The $\mathrm{pH}$ values of cheese whey during cheese production and of myzithra cheese

207 during storage were measured using a digital $\mathrm{pH}$ meter by direct immersion of the 208 electrode (EPI-BION SENTRON pH-System 1001).

209 Myzithra cheese samples (20 g each) were macerated with warm water $\left(40{ }^{\circ} \mathrm{C}\right)$ 210 to produce a total volume of $210 \mathrm{~mL}$ and then each sample was filtered and used for 
211 the identification of total acidity and lactose concentration. A quantity of $25 \mathrm{~mL}$ from

212 the above filtrate was used for titration with $0,1 \mathrm{~N} \mathrm{NaOH}$ and phenolphthalein

213 indicator. Total acidity was determined to the official method by AOAC International

214 (2000) and expressed as lactic acid content. Lactose was determined by high

215 performance liquid chromatography, using a Shimadzu chromatograph with a SCR-

$216101 \mathrm{~N}$ stainless steel column, a LC-9A pump, a CTO-10A oven at $60{ }^{\circ} \mathrm{C}$ and a RID-

217 6A refractive index detector as described previously by A. Terpou et al. (2017).

218 Lactose concentrations were calculated using standard curves.

\subsection{Solid phase microextraction gas chromatography-mass spectrometry analysis}

221 Samples of myzithra cheese with adjunct free (F) or adjunct microencapsulated (ME)

L. casei cells were studied for terpenoid content as an aroma profile indicator using

SPME GC-MS analysis and compared with control myzithra cheese samples (C). For the analysis, myzithra cheese samples $(7.0 \mathrm{~g}$ each $)$ from the $1^{\text {st }}$ day of storage $\left(4^{\circ} \mathrm{C}\right)$ were introduced into a $20 \mathrm{~mL}$ headspace vial fitted with a Teflon-lined septum and sealed with an aluminum crimp seal. Through the seal a syringe needle (Supelco, Bellefonte, PA, USA) was inserted. The container was then thermostated for $5 \mathrm{~min}$ at $60{ }^{\circ} \mathrm{C}$ with the syringe closed and when the temperature was stable the syringe was introduced at the gas area of the vial for $45 \mathrm{~min}$ at $60{ }^{\circ} \mathrm{C}$.

230 The absorbed volatile analytes were then analyzed by GC-MS (Shimadzu GC-

231 17A, MS QP5050, capillary column Supelco CO Wax-10 60 m, 0.32 mm i.d., 0.25

$232 \mu \mathrm{m}$ film thickness) as described previously by A. Terpou et al. (2017). The 233 identification of the absorbed terpenoid content, presented $\%$ in total area of 234 hydrocarbons, was performed by comparing the retention times with those of 235 authentic compounds, by mass spectra of the authentic compounds generated in the 
236 laboratory, by mass spectra obtained from NIST107, NIST21 and SZTERP libraries

237 and by determining kovats' retention indexes compared with those reported in the

238 literature. Kovats' retention indexes (KI) were determined by injection of a standard

239 mixture containing the homologous series of normal alkanes (C7-C32) in pure hexane

240 under exactly the same experimental conditions, as described above.

\subsection{Myzithra cheese sensory evaluation}

243 Sensory evaluation of cheese is necessary in order to determine the influence of 244 cheese composition on sensory characteristics, eating quality and consumers 245 acceptability. Sensory evaluation was carried out by 10 laboratory members, priory 246 trained, using locally approved protocols. Samples were tested by two different 247 laboratories (5 members each) and all members were from different parts of the 248 country. Consumers selection criteria were between $20 \sim 45$ years of age, and frequent 249 users of cheese (>once a week). The questions asked and procedure of cheese testing 250 were identical for the two laboratories. Myzithra cheese samples from the $1^{\text {st }}$ storage 251 day $\left(4^{\circ} \mathrm{C}\right)$ were placed into equivalent amounts of $5 \times 5 \mathrm{~cm}$ and served at room 252 temperature $\left(18 \sim 22{ }^{\circ} \mathrm{C}\right)$. This procedure was chosen as consumers normally will 253 consume cheese directly from refrigerator. Sensory analysis was carried out in panel 254 booths conforming to international standards (International standard, 2007). The 255 samples were coded by a different 3-digital number each and were served in a 256 randomized order while the panel was asked to evaluate all myzithra cheeses $(\mathrm{C}, \mathrm{F}$, 257 ME, MF) on a $0-10$ scale (the higher the number the greater the intensity) based on 258 saltiness, acidity, bitterness, sweetness, chewiness, cheese odor, mastic odor and 259 overall acceptability. Data from both laboratories were handled as one data set during 260 statistical analysis. The results are presented as a star chart of the product's attributes. 
$262 \quad 2.8$ Experimental design and statistical analysis

263 Myzithra cheese production and analysis was carried out in triplicate and results are

264 presented as mean values \pm standard deviation. All experiments were designed and

265 analyzed statistically by ANOVA. Significant differences among results (coefficients,

266 ANOVA tables and significance) which were computed using SPSS v.8.5. 


\section{Results and Discussion}

\subsection{Rational}

Whey cheeses are prepared by denaturation and precipitation of whey proteins $(\alpha-$ lactalbumin, $\beta$-lactoglobulin) achieved by heating whey effluent at approximately at $85{ }^{\circ} \mathrm{C}$. In Greece traditionally, whey cheeses like myzithra cheese are consumed as table cheeses. They have high nutritional value, low fat and salt content and have good organoleptic characteristics and are therefore great vehicles for incorporation of probiotics (Papaioannou, Chouliara, Karatapanis, Kontominas, \& Savvaidis, 2007).

However, freshly made whey cheeses have a $\mathrm{pH}$ value of greater than 6 , high moisture content and a low salt concentration and are therefore considered to be extremely sensitive to microbial deterioration (Hough, Puglieso, Sanchez, \& da Silva, 1999) with very short shelf-life reaching up to 7 days under aerobic conditions (Samelis, Kakouri, Rogga, Savvaidis, \& Kontominas, 2003).

In contrast, Pistacia terebinthus resin has been proved to confer an antimicrobial effect to dairy products due to its high terpenoid characteristics (Schoina et al., 2014). Moreover, immobilisation in various natural supports has been proved to enhance the viability of probiotic cells by a protective film that is formed by each immobilisation support protecting cells against the acidic environment of dairy products (Bosnea, Kopsahelis, Kokkali, Terpou, \& Kanellaki, 2017; Antonia Terpou et al., 2017; A. Terpou et al., 2017). Thus, Pistacia terebinthus resin was assessed as encapsulation matrix for Lactobacillus casei cells and incorporated in myzithra cheese.

\subsection{The probiotic encapsulated biocatalyst}

Electron micrographs reinsured encapsulation of the probiotic cells within the viscous 
292 matrix of Pistacia terebinthus (Fig. 1). The average encapsulation yield obtained in

293 the present study was reported by experiments carried out on the encapsulated

294 biocatalyst presenting an average of $1.56 \mathrm{~g}$ of $L$. casei cells successfully encapsulated

295 in $100 \mathrm{~g}$ of Pistacia terebinthus (data not shown). More analytically, in each $5 \mathrm{~g}$ of the

296 resin $7.8 \%$ of the initial probiotic culture is encapsulated (data not shown).

297 Subsequently, 4 log CFU of L. casei cells were proved to be encapsulated in each 298 gram of Pistacia terebinthus' viscus matrix.

3.3 Effect of the encapsulated biocatalyst on growth of foodborne pathogens, cheese microflora, and spoilage microorganisms

302 Myzithra cheese samples were tested for their microbial stability as a shelf-life 303 indicator, through refrigerated storage for 30 days (Table 1). No coliforms, 304 enterobacteria or Staphylococcus aureus were detected in any myzithra cheese. There

305 was observed a significant amount of yeast and fungi in all myzithra cheeses from the $3061^{\text {st }}$ storage day $\left(2.6 \sim 2.7 \log \mathrm{CFU} \mathrm{g}^{-1}\right)$ which in the case of control cheeses (C) 307 increased significantly until the $30^{\text {th }}$ storage day $\left(4.7 \log \mathrm{CFU} \mathrm{g}{ }^{-1}\right)$. On the other hand, 308 yeast and fungi showed a sharp decrease in the case of cheese samples with 309 incorporated Pistacia terebinthus resin either added as an encapsulation support (ME) 310 or as an adjunct (MF). Myzithra cheese which is usually consumed within 7 days 311 from production and does not have yeast and fungi as a naturally occurring 312 microflora. When high numbers of the prementioned microorganisms are detected the 313 cheese is most likely accompanied by a bad odor and cannot be consumed.

314 The addition of the probiotic strain, either free or encapsulated, affected 315 significantly $(\mathrm{P}<0.05)$ the total lactobacilli counts of myzithra cheese after the $1^{\text {st }}$ 316 storage day (F, ME, MF), compared to control cheese (C). Moreover, in all myzithra 
317 samples was detected a significant amount of Lactococci $\left(2.9 \sim 2.0 \log \mathrm{CFU} \mathrm{g}{ }^{-1}\right)$ that

318 did not significantly differ among cheese samples during 30 days of storage. Their

319 presence in cheeses may occur due to non-starter lactic acid bacteria and cross-

320 contamination during cheese production (Kalogridou-Vassiliadou, Tzanetakis, \&

321 Litopoulou-Tzanetaki, 1994).

\subsection{Growth capacity of the adjunct probiotic strain during refrigerated storage}

324 Cheese presents a good vehicle for the delivery of probiotics in the intestine, while the

maintenance of viable probiotic cell counts at high level by the end of expiration date

is most crucial in such products in order to confer most health benefits. In this vein,

experiments were carried out in order to evaluate the effect of Pistacia terebinthus

resin and myzithra cheese storage conditions on viability of L. casei cells. Figure 2

329 shows the \% viability of $L$. casei added either as a free culture, as an encapsulated

330 culture in Pistacia terebinthus resin or as a free culture along with resin particles,

331 during storage at $4^{\circ} \mathrm{C}$ for 30 days. All myzithra cheeses in which L. casei was

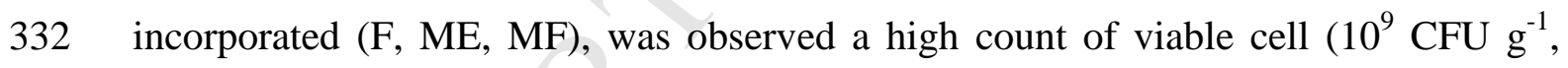

333 data not shown) during storage. This result indicated the probiotic character of the 334 products.

335 More specifically, the survival rates of encapsulated L. casei was $8.2 \%$ by the 336 end of storage period while in contrast L. casei free cells along with resins 337 incorporated particles were reduced down to $4 \%$. The lowers viability rates were 338 observed in the case of free L. casei cells which were reduced down to $8.2 \%$. These 339 results occurred most likely due to the absence of $P$. terebinthus resin and its 340 antimicrobial effects allowing foodborne microorganisms like yeast and fungi (Table 341 1) to grow at the expense of probiotic cells. Since myzithra cheeses with encapsulated 
342 biocatalyst showed the higher survival rates during storage we can assume that

343 encapsulation acts protectively to probiotic cells against storage conditions and cheese

344 environment.

\subsection{Physicochemical characteristics of myzithra cheeses}

347 During storage, lactose concentration, $\mathrm{pH}$ values and total acidity were determined for

348 all myzithra cheeses and the results are presented in Table 2. In most whey cheeses

349 prepared by the incorporation of lactic acid bacteria there has been observed a higher

350 content of total acidity and a parallel with $\mathrm{pH}$ decrease, compared to whey cheeses

351 prepared with the traditional recipe (Madureira et al., 2008; Madureira et al., 2015).

352 As expected, a continuous increase of total acidity was observed during 30 storage

353 days and ranged in acceptable levels for all myzithra cheese products (Anifantakis,

354 1991; Kalogridou-Vassiliadou et al., 1994). The total acidity of the whey cheeses was

355 affected by the adjunct probiotic culture. Specifically, myzithra cheeses with $L$. casei

356 culture (free or encapsulated) showed an acidity significantly higher $(\mathrm{P}<0.05)$

357 compared to control myzithra cheeses prepared with no additional culture. In

358 particular, total acidity increased from 0.3 to $0.5 \mathrm{~g}$ of lactic acid per $100 \mathrm{~g}$ of cheese in

359 myzithra samples free $L$. casei cells (F) and an increase from 0.3 to $0.6 \mathrm{~g}$ of lactic acid

360 / $100 \mathrm{~g}$ of cheese in the case of myzithra samples with encapsulated L. casei cells

361 (ME). No significant differences were observed in myzithra cheese samples with free

362 L. casei cells (F) and cheese samples with Pistacia terebinthus resin and free L. casei

363 cells $(\mathrm{MF})$. In parallel with total acidity increase, there was observed a $\mathrm{pH}$ reduction

364 most likely as a result of continuous growth of microorganisms during refrigerated

365 storage as it can be reinsured by microbiological analysis (Table 1). Regarding the $\mathrm{pH}$

366 of traditional whey cheese produced without an adjunct culture the presented values 
367 are significantly higher (Pappa, Samelis, Kondyli, \& Pappas, 2016) than those of

368 whey cheeses like myzithra produced with the incorporation L. casei.

369 Lactose accumulation was observed in all cheese samples and ranged in usual

370 levels of commercial myzithra cheeses (Kaminarides, 2015), while no significant

371 differences were observed within the samples. Nevertheless, lactose content was

372 lower in myzithra cheeses produced with either free or encapsulated probiotic cells 373 compared to traditionally made myzithra cheese. This trend was expected due to the 374 presence of live probiotic cells during storage (Kourkoutas et al., 2006; A. Terpou et 375 al., 2017).

\subsection{Effect of Pistacia terebinthus resin on volatile by-products of myzithra cheese}

378 The majority of volatiles, especially ones' that define a characteristic aroma to cheese 379 products, were identified in myzithra cheeses with encapsulated biocatalyst (ME) by

380 SPME/ GC-MS analysis and are presented as \% of the total area of hydrocarbons' 381 content (Table 3). A large number of terpenoid compounds, predominantly $\alpha$-pinene 382 (Table 3), appear in the produced myzithra cheeses with encapsulated $L$. casei cells 383 (ME), due solely to added Pistacia terebinthus resin (pissa Paphos). Additionally, in 384 Figure $3 \mathrm{~A}$ is highlighted the plethora of terpenoid compounds of myzithra cheese with 385 encapsulated biocatalyst (ME) presented on the chromatograph of headspace analysis.

386 Concerning total terpenoid content (Figure 3B), total mono-terpenes were found to be $38790.9 \%$ and total oxygenated mono-terpenes $9.1 \%$. Monoterpenes have been reported 388 as potential antimicrobial agents, as antiviral agents, antifungal agents and as potential 389 antioxidants while they can also be used as ingredients of soaps, perfumes, and food 390 additives (Armaka, Papanikolaou, Sivropoulou, \& Arsenakis, 1999; Prates et al., 391 1998; Ruberto \& Baratta, 2000; Zhang et al., 2016). Figure 3B shows the distribution 
392 of terpenoid components of myzithra cheese with encapsulate biocatalyst $(0.5 / 100 \mathrm{~g}$

393 of product), in which the higher content of monoterpenes was detected as is $\alpha$-pinene

394 (84.5\%). These results were mostly expected as essential oils of three Pistacia species

395 compile mainly of $\alpha$-pinene, $\beta$-pinene, limonene and $\alpha$-terpineol (Duru et al., 2003).

396 Likewise, the significant influence of a-pinene in myzithra cheeses with encapsulated

397 biocatalyst indicates the reins' antimicrobial effects against spoilage microorganisms

398 (Kivrak et al., 2009) resulting to a possibly extended shelf-life of functional myzithra

399 cheeses. Moreover, apart from $\alpha$-pinen the detected $\alpha$-terpineol (1.3\%), eucalyptol

$400(0.3 \%)$ and linalool $(0.2 \%)$ can provide antibacterial and antioxidant effects to

401 produced cheeses (Zengin \& Baysal, 2014). In addition, according Park et al. (2012)

402 linalool and $\alpha$-terpineol provides an antimicrobial effect against periodontopathic and 403 cariogenic bacteria. Thus, the antibacterial, antifungal and antioxidant activities of 404 such monoterpenes result to the conclusion that $P$. terebinthus resin can be used as a 405 natural preservative of food products with good organoleptic characteristics.

406 Another important influence of the incorporated resin with encapsulated 407 probiotic cells refers to improved aromatic profile of myzithra cheeses. The numerus 408 monoterpenes originating from the incorporated resin are well known for their 409 contribution to the aromatic profile of products and are very often used as additives in 410 food production (Prates et al., 1998). Most of detected terpenes are characterized by 411 exceptional aromatic characteristics and can contribute to flavor of produced cheese 412 due to their low threshold value. For example, $\alpha$-pinene is known for its pine odor, 3413 carene $(0.2 \%)$ its sweet lemon odor and linalool $(0.2 \%)$ for its sweet floral odor 414 (Curioni \& Bosset, 2002; Vichi et al., 2007). Apart from their floral and fruity 415 aromas, monoterpenes are also considered important compounds because of their 416 ability to reduce the effects of unpleasant odors caused by phenolic compounds or 
417 short chain fatty acids (Curioni \& Bosset, 2002).

418 The results indicated that the plethora of terpenoid compounds were detected

419 in myzithra cheese due to the incorporation of $P$. terebinthus resin. In addition, by

420 GCMS/ SPME analysis has highlighted that the use of $P$. terebinthus resin as

421 encapsulation support leads to exceptional aromatic characteristics of produced 422 myzithra cheeses, which is also in agreement with the sensory evaluation results.

\subsection{Myzithra cheese sensory evaluation}

425 Sensory evaluation of myzithra cheese samples is presented in Figure 4. The results of 426 sensory evaluation of myzithra cheese samples are presented in Figure 4. In most 427 cases, no significant differences were observed between myzithra cheeses produced 428 by adjunct $P$. terebinthus resin with either free or encapsulated probiotic cells. 429 However, samples prepared without the present of the resin (C, F) presented 430 significantly $(\mathrm{P}<0.05)$ lower values in all cases compared to myzithra cheese 431 samples in which $P$. terebinthus resin was added as an adjunct. These findings 432 indicated the high industrialization potential of the proposed technology since sensory 433 evaluation showed high consumers preference referring to all novel myzithra cheeses 434 with incorporated Pistacia terebinthus resin.

\section{Conclusions}

437 The production of a novel functional whey cheese by the adjunct encapsulated $L$. 438 casei in Pistacia terebinthus resin (pissa Paphos) was assessed in the present study. 439 The probiotic cells were successfully encapsulated in the viscus matric of the resin 440 retaining its viability despite the resins' antimicrobial properties. The obtained results 441 showed that encapsulation favored the viability of L. casei in refrigerated storage 
442 while the antimicrobial properties of the resin resulted in shelf-life extension of the

443 produced myzithra cheeses. In the present study, was highlighted the potential use of

444 pissa Paphos as a lactobacilli microencapsulation support, as an antimicrobial additive

445 and as an aromatic enhancement material indicating its future use in nutraceutical and

446 food industry.

447

448 5. Acknowledgements

449 Schoina $V$. would like to thank the State Scholarships Foundation (IKY) for the 450 financial support in the frame of her $\mathrm{PhD}$ thesis. 
452 Aksoy, A., Duran, N., \& Koksal, F. (2006). In vitro and in vivo antimicrobial effects 453 of mastic chewing gum against Streptococcus mutans and mutans streptococci. 454 Archives of Oral Biology, 51(6), 476-481. doi: 455 https://doi.org/10.1016/j.archoralbio.2005.11.003

456 Anifantakis, E. M. (1991). Greek Cheeses: A Tradition of Centuries: National Dairy 457 Committee of Greece.

458 Armaka, M., Papanikolaou, E., Sivropoulou, A., \& Arsenakis, M. (1999). Antiviral 459 properties of isoborneol, a potent inhibitor of herpes simplex virus type 1. Antiviral 460 Res, 43(2), 79-92.

461 Bogue, J., Collins, O., \& Troy, A. J. (2017). Chapter 2 - Market analysis and concept 462 development of functional foods - Bagchi, Debasis. In S. Nair (Ed.), Developing New 463 Functional Food and Nutraceutical Products (pp. 29-45). San Diego: Academic Press.

464 Bosnea, L. A., Kopsahelis, N., Kokkali, V., Terpou, A., \& Kanellaki, M. (2017). 465 Production of a novel probiotic yogurt by incorporation of $L$. casei enriched fresh 466 apple pieces, dried raisins and wheat grains. Food and Bioproducts Processing, 102, 467 62-71. doi: 10.1016/j.fbp.2016.11.010

468 Bosnea, L. A., Moschakis, T., Nigam, P. S., \& Biliaderis, C. G. (2017). Growth 469 adaptation of probiotics in biopolymer-based coacervate structures to enhance cell 470 viability. LWT - Food Science and Technology, 77, 282-289. doi: $471 \quad$ 10.1016/j.lwt.2016.11.056

472 Bozoudi, D., Pavlidou, S., Kotzamanidis, C., Georgakopoulos, P., Torriani, S., 
473 Kondyli, E., . . . Litopoulou-Tzanetaki, E. (2016). "Graviera Naxou and Graviera

474 Kritis Greek PDO cheeses: Discrimination based on microbiological and 475 physicochemical criteria and volatile organic compounds profile". Small Ruminant 476 Research, 136, 161-172. doi: https://doi.org/10.1016/j.smallrumres.2016.01.022

477 Caleja, C., Barros, L., Antonio, A. L., Carocho, M., Oliveira, M. B. P. P., \& Ferreira, I. 478 C. F. R. (2016). Fortification of yogurts with different antioxidant preservatives: A 479 comparative study between natural and synthetic additives. Food Chemistry, 210, 262480 268. doi: https://doi.org/10.1016/j.foodchem.2016.04.114

481 Carocho, M., Barreiro, M. F., Morales, P., \& Ferreira, I. C. F. R. (2014). Adding 482 Molecules to Food, Pros and Cons: A Review on Synthetic and Natural Food 483 Additives. Comprehensive Reviews in Food Science and Food Safety, 13(4), 377-399. 484 doi: 10.1111/1541-4337.12065

485 Champagne, C. P., Ross, R. P., Saarela, M., Hansen, K. F., \& Charalampopoulos, D. 486 (2011). Recommendations for the viability assessment of probiotics as concentrated 487 cultures and in food matrices. International Journal of Food Microbiology, 149(3), 488 185-193. doi: 10.1016/j.ijfoodmicro.2011.07.005

489 Chemists, A. o. O. A. (2000). Official methods of analysis of the AOAC: Association 490 of Official Analytical Chemists.

491 Curioni, P. M. G., \& Bosset, J. O. (2002). Key odorants in various cheese types as 492 determined by gas chromatography-olfactometry. International Dairy Journal, 12(12), 493 959-984. doi: 10.1016/S0958-6946(02)00124-3

494 Daifas, D. P., Smith, J. P., Blanchfield, B., Sanders, G., Austin, J. W., \& Koukoutisis, 495 J. (2004). Effects of mastic resin and its essential oil on the growth of proteolytic 
496 Clostridium botulinum. International Journal of Food Microbiology, 94(3), 313-322.

497 doi: https://doi.org/10.1016/j.ijfoodmicro.2004.01.017

498 Dell, B., \& McComb, A. J. (1979). Plant Resins-Their Formation, Secretion and 499 Possible Functions. Advances in Botanical Research, 6, 277-316. doi: 500 http://dx.doi.org/10.1016/S0065-2296(08)60332-8

501 Duru, M. E., Cakir, A., Kordali, S., Zengin, H., Harmandar, M., Izumi, S., \& Hirata, T. 502 (2003). Chemical composition and antifungal properties of essential oils of three 503 Pistacia species. Fitoterapia, 74(1-2), 170-176. doi: https://doi.org/10.1016/S0367$504326 \mathrm{X}(02) 00318-0$

505 Fuller, R., \& Gibson, G. R. (1998). Probiotics and prebiotics: microflora management 506 for improved gut health. Clinical Microbiology and Infection, 4(9), 477-480. doi: 507 http://dx.doi.org/10.1111/j.1469-0691.1998.tb00401.x

508 Gardeli, C., Papageorgiou, V., Mallouchos, A., Kibouris, T., \& Komaitis, M. (2008). 509 Essential oil composition of Pistacia lentiscus L. and Myrtus communis L.: Evaluation 510 of antioxidant capacity of methanolic extracts. Food Chemistry, 107(3), 1120-1130. 511 doi: https://doi.org/10.1016/j.foodchem.2007.09.036

512 Goodner, K. L. (2008). Practical retention index models of OV-101, DB-1, DB-5, and 513 DB-Wax for flavor and fragrance compounds. LWT - Food Science and Technology, 514 41(6), 951-958. doi: https://doi.org/10.1016/j.lwt.2007.07.007

515 Högnadóttir, Á., \& Rouseff, R. L. (2003). Identification of aroma active compounds in 516 orange essence oil using gas chromatography-olfactometry and gas chromatography517 mass spectrometry. Journal of Chromatography A, 998(1-2), 201-211. doi: 518 https://doi.org/10.1016/S0021-9673(03)00524-7 
519 Hough, G., Puglieso, M. L., Sanchez, R., \& da Silva, O. M. (1999). Sensory and

520 Microbiological Shelf-Life of a Commercial Ricotta Cheese. Journal of Dairy

521 Science, 82(3), 454-459. doi: http://dx.doi.org/10.3168/jds.S0022-0302(99)75253-7

522 International standard ISO 8589: Sensory analysis: General guidance for the design of

523 test rooms. International Organization for Standardization (2007).

524 Kalogridou-Vassiliadou, D., Tzanetakis, N., \& Litopoulou-Tzanetaki, E. (1994).

525 Microbiological and physicochemical characteristics of 'Anthotyro', a Greek 526 traditional whey cheese. Food Microbiology, 11(1), 15-19. doi: 527 https://doi.org/10.1006/fmic.1994.1003

528 Kaminarides, S. (2015). A modified form of Myzithra cheese produced by substituting 529 the fresh cheese whey by dried whey protein concentrate and ovine milk and cream. 530 Small Ruminant $\quad$ Research, $\quad 131, \quad 118-122 . \quad$ doi: 531 https://doi.org/10.1016/j.smallrumres.2015.07.020

532 Kivrak, İ., Duru, M. E., Öztürk, M., Mercan, N., Harmandar, M., \& Topçu, G. (2009). 533 Antioxidant, anticholinesterase and antimicrobial constituents from the essential oil 534 and ethanol extract of Salvia potentillifolia. Food Chemistry, 116(2), 470-479. doi: 535 http://dx.doi.org/10.1016/j.foodchem.2009.02.069

536 Kourkoutas, Y., Bosnea, L., Taboukos, S., Baras, C., Lambrou, D., \& Kanellaki, M. 537 (2006). Probiotic cheese production using Lactobacillus casei cells immobilized on 538 fruit pieces. [Article]. Journal of Dairy Science, 89(5), 1439-1451.

539 Lardos, A. (2006). The botanical materia medica of the Iatrosophikon-A collection 540 of prescriptions from a monastery in Cyprus. Journal of Ethnopharmacology, 104(3), 541 387-406. doi: https://doi.org/10.1016/j.jep.2005.12.035 
542 Lee, S.-J., Umano, K., Shibamoto, T., \& Lee, K.-G. (2005). Identification of volatile 543 components in basil (Ocimum basilicum L.) and thyme leaves (Thymus vulgaris L.) 544 and their antioxidant properties. Food Chemistry, 91(1), 131-137. doi: 545 https://doi.org/10.1016/j.foodchem.2004.05.056

546 Litopoulou-Tzanetaki, E., \& Tzanetakis, N. (2011). Microbiological characteristics of 547 Greek traditional cheeses. Small Ruminant Research, 101(1-3), 17-32. doi: 548 https://doi.org/10.1016/j.smallrumres.2011.09.022

549 Madureira, A. R., Soares, J. C., Pintado, M. E., Gomes, A. M. P., Freitas, A. C., \& 550 Malcata, F. X. (2008). Sweet whey cheese matrices inoculated with the probiotic 551 strain Lactobacillus paracasei LAFTI® L26. Dairy Science \& Technology, 88(6), 552 649-665. doi: 10.1051/dst:2008026

553 Madureira, A. R., Soares, J. C., Pintado, M. E., Gomes, A. M. P., Freitas, A. C., \& 554 Xavier Malcata, F. (2015). Effect of the incorporation of salted additives on probiotic 555 whey cheeses. Food Bioscience, 10, 8-17. doi: 556 https://doi.org/10.1016/j.fbio.2015.01.004

557 Mallouchos, A., Paul, L., Bekatorou, A., Koutinas, A., \& Komaitis, M. (2007). 558 Ambient and low temperature winemaking by immobilized cells on brewer's spent 559 grains: Effect on volatile composition. Food Chemistry, 104(3), 918-927. doi: 560 https://doi.org/10.1016/j.foodchem.2006.12.047

561 Morales, M. E., \& Ruiz, M. A. (2016). 16 - Microencapsulation of probiotic cells: 562 applications in nutraceutic and food industry - Grumezescu, Alexandru Mihai 563 Nutraceuticals (pp. 627-668): Academic Press.

564 Morkhade, D. M. Evaluation of gum mastic (pistacia lentiscus) as a 
565 microencapsulating and matrix forming material for sustained drug release. Asian

566 Journal of Pharmaceutical Sciences. doi: https://doi.org/10.1016/j.ajps.2017.05.002

567 Papaioannou, G., Chouliara, I., Karatapanis, A. E., Kontominas, M. G., \& Savvaidis,

568 I. N. (2007). Shelf-life of a Greek whey cheese under modified atmosphere 569 packaging. International Dairy Journal, 17(4), 358-364. doi: 570 https://doi.org/10.1016/j.idairyj.2006.04.001

571 Pappa, E. C., Samelis, J., Kondyli, E., \& Pappas, A. C. (2016). Characterisation of 572 Urda whey cheese: Evolution of main biochemical and microbiological parameters 573 during ripening and vacuum packaged cold storage. International Dairy Journal, 58, 574 54-57. doi: https://doi.org/10.1016/j.idairyj.2015.12.016

575 Pappas, C., \& Voutsinas, L. (2009). Effect of acidification of sheep's cheese whey 576 with organic acids on the retention of protein and on the quality of Myzithra cheese. 577 Journal of Dairy Research, 55(2), 247-254. doi: 10.1017/S0022029900026078

578 Paraschos, S., Magiatis, P., Gousia, P., Economou, V., Sakkas, H., Papadopoulou, C., $579 \&$ Skaltsounis, A.-L. (2011). Chemical investigation and antimicrobial properties of 580 mastic water and its major constituents. Food Chemistry, 129(3), 907-911. doi: 581 https://doi.org/10.1016/j.foodchem.2011.05.043

582 Park, S.-N., Lim, Y. K., Freire, M. O., Cho, E., Jin, D., \& Kook, J.-K. (2012). 583 Antimicrobial effect of linalool and $\alpha$-terpineol against periodontopathic and 584 cariogenic bacteria. Anaerobe, 18(3), 369-372. doi: 585 http://dx.doi.org/10.1016/j.anaerobe.2012.04.001

586 Prates, H. T., Santos, J. P., Waquil, J. M., Fabris, J. D., Oliveira, A. B., \& Foster, J. E. 587 (1998). Insecticidal activity of monoterpenes against Rhyzopertha dominica (F.) and 
588 Tribolium castaneum (Herbst). Journal of Stored Products Research, 34(4), 243-249.

589 doi: http://dx.doi.org/10.1016/S0022-474X(98)00005-8

590 Rauf, A., Patel, S., Uddin, G., Siddiqui, B. S., Ahmad, B., Muhammad, N., . . Hadda,

591 T. B. (2017). Phytochemical, ethnomedicinal uses and pharmacological profile of 592 genus Pistacia. Biomedicine \& Pharmacotherapy, 86, 393-404. doi: 593 https://doi.org/10.1016/j.biopha.2016.12.017

594 Ruberto, G., \& Baratta, M. T. (2000). Antioxidant activity of selected essential oil 595 components in two lipid model systems. Food Chemistry, 69(2), 167-174. doi: 596 http://dx.doi.org/10.1016/S0308-8146(99)00247-2

597 Samelis, J., Kakouri, A., Rogga, K. J., Savvaidis, I. N., \& Kontominas, M. G. (2003). 598 Nisin treatments to control Listeria monocytogenes post-processing contamination on 599 Anthotyros, a traditional Greek whey cheese, stored at $4^{\circ} \mathrm{C}$ in vacuum packages. Food 600 Microbiology, 20(6), 661-669. doi: https://doi.org/10.1016/S0740-0020(03)00018-2

601 Saxami, G., Ypsilantis, P., Sidira, M., Simopoulos, C., Kourkoutas, Y., \& Galanis, A. 602 (2012). Distinct adhesion of probiotic strain Lactobacillus casei ATCC393 to rat 603 intestinal mucosa. Anaerobe, 18(4), 417-420. doi: 604 http://dx.doi.org/10.1016/j.anaerobe.2012.04.002

605 Schoina, V., Terpou, A., Angelika-Ioanna, G., Koutinas, A., Kanellaki, M., \& Bosnea, 606 L. (2014). Use of Pistacia terebinthus resin as immobilization support for 607 Lactobacillus casei cells and application in selected dairy products. Journal of Food 608 Science and Technology. doi: 10.1007/s13197-014-1627-9

609 Schoina, V., Terpou, A., Angelika-Ioanna, G., Koutinas, A., Kanellaki, M., \& Bosnea, 610 L. (2015). Use of Pistacia terebinthus resin as immobilization support for 
611 Lactobacillus casei cells and application in selected dairy products. Journal of Food

612 Science and Technology, 52(9), 5700-5708. doi: 10.1007/s13197-014-1627-9

613 Shiratsuchi, H., Shimoda, M., Minegishi, Y., \& Osajima, Y. (1993). Isolation and

614 identification of volatile flavor compounds in nonfermented coarse-cut sausage.

615 Flavor as a quality factor of nonfermented sausage. 1. Journal of Agricultural and

616 Food Chemistry, 41(4), 647-652. doi: 10.1021/jf00028a027

617 Shori, A. B. (2015). The potential applications of probiotics on dairy and non-dairy

618 foods focusing on viability during storage. Biocatalysis and Agricultural

619 Biotechnology, 4(4), 423-431. doi: https://doi.org/10.1016/j.bcab.2015.09.010

620 Terpou, A., Bekatorou, A., Kanellaki, M., Koutinas, A. A., \& Nigam, P. (2017).

621 Enhanced probiotic viability and aromatic profile of yogurts produced using wheat 622 bran (Triticum aestivum) as cell immobilization carrier. Process Biochemistry, 55, 1623 10. doi: https://doi.org/10.1016/j.procbio.2017.01.013

624 Terpou, A., Gialleli, A. I., Bosnea, L., Kanellaki, M., Koutinas, A. A., \& Castro, G. R. 625 (2017). Novel cheese production by incorporation of sea buckthorn berries 626 (Hippophae rhamnoides L.) supported probiotic cells. [Article]. LWT - Food Science 627 and Technology, 79, 616-624. doi: 10.1016/j.lwt.2016.11.021

628 Tharmaraj, N., \& Shah, N. P. (2003). Selective Enumeration of Lactobacillus 629 delbrueckii ssp. bulgaricus, Streptococcus thermophilus, Lactobacillus acidophilus, 630 Bifidobacteria, Lactobacillus casei, Lactobacillus rhamnosus, and Propionibacteria. 631 Journal of Dairy Science, 86(7), 2288-2296. doi: https://doi.org/10.3168/jds.S0022$632 \quad 0302(03) 73821-1$

633 Topçu, G., Ay, M., Bilici, A., Sarıkürkcü, C., Öztürk, M., \& Ulubelen, A. (2007). A 
634 new flavone from antioxidant extracts of Pistacia terebinthus. Food Chemistry,

635 103(3), 816-822. doi: https://doi.org/10.1016/j.foodchem.2006.09.028

636 Vichi, S., Riu-Aumatell, M., Mora-Pons, M., Guadayol, J. M., Buxaderas, S., \&

637 López-Tamames, E. (2007). HS-SPME coupled to GC/MS for quality control of

638 Juniperus communis L. berries used for gin aromatization. Food Chemistry, 105(4),

639 1748-1754. doi: https://doi.org/10.1016/j.foodchem.2007.03.026

640 Zengin, H., \& Baysal, A. H. (2014). Antibacterial and antioxidant activity of essential

641 oil terpenes against pathogenic and spoilage-forming bacteria and cell structure-

642 activity relationships evaluated by SEM microscopy. Molecules, 19(11), 17773-

643 17798. doi: 10.3390/molecules 191117773

644 Zhang, Z., Yang, T., Mi, N., Wang, Y., Li, G., Wang, L., \& Xie, Y. (2016). Antifungal

645 activity of monoterpenes against wood white-rot fungi. International Biodeterioration

646 \& Biodegradation, 106, 157-160. doi: http://dx.doi.org/10.1016/j.ibiod.2015.10.018 


\section{$647 \quad$ Figure captions}

648

649 Figure 1. Electron micrographs of Pistacia terebinthus resin surface (A), L. casei 650 ATCC 393 cells in Pistacia terebinthus encapsulating matrix (B, C).

651

652 Figure 2. L. casei \% viability during refrigerated storage $\left(4^{\circ} \mathrm{C}\right)$ for 30 days.

653

654 Figure 3. SPME GC-MS spectra (full scan mode chromatogram) of myzithra cheese 655 with adjunct L. casei cells encapsulated in Pistacia terebinthus resin (ME).

656

657 Figure 4. Sensory evaluation of produced myzithra chesses from the $1^{\text {st }}$ day of storage 658 at $4^{\circ} \mathrm{C}$. 
659 Table 1. Myzithra cheese microbial population ( $\log \mathrm{CFU} \mathrm{g} \mathrm{g}^{-1} \pm$ ) during 30 days of 660 storage $\left(4^{\circ} \mathrm{C}\right)$.

\begin{tabular}{ccccccc}
\hline $\begin{array}{c}\text { Myzithra } \\
\text { cheese }\end{array}$ & $\begin{array}{c}\text { Storage } \\
\text { time } \\
\text { (days) }\end{array}$ & $\begin{array}{c}\text { Total } \\
\text { aerobic } \\
\text { counts }\end{array}$ & Lactococci & Lactobacilli & $\begin{array}{c}\text { Yeasts \& } \\
\text { fungi }\end{array}$ & Staphylococci \\
\hline \multirow{4}{*}{ C } & 1 & $3.78^{ \pm 0.19}$ & $2.80^{ \pm 0.14}$ & $2.97^{ \pm 0.15}$ & $2.68^{ \pm 0.08}$ & $1.98^{ \pm 0.10}$ \\
& 5 & $4.30^{ \pm 0.21}$ & $2.85^{ \pm 0.15}$ & $2.66^{ \pm 0.13}$ & $3.30^{ \pm 0.12}$ & $1.92^{ \pm 0.09}$ \\
& 7 & $4.65^{ \pm 0.23}$ & $2.70^{ \pm 0.14}$ & $2.57^{ \pm 0.13}$ & $3.62^{ \pm 0.13}$ & $2.14^{ \pm 0.11}$ \\
& 14 & $4.75^{ \pm 0.24}$ & $2.75^{ \pm 0.14}$ & $2.85^{ \pm 0.15}$ & $4.42^{ \pm 0.12}$ & $2.21^{ \pm 0.11}$ \\
& 30 & $5.78^{ \pm 0.29}$ & $2.78^{ \pm 0.14}$ & $2.74^{ \pm 0.19}$ & $4.73^{ \pm 0.12}$ & $2.25^{ \pm 0.11}$ \\
\hline \multirow{4}{*}{ F } & 1 & $3.30^{ \pm 0.17}$ & $2.83^{ \pm 0.15}$ & $9.97^{ \pm 0.17}$ & $2.60^{ \pm 0.08}$ & $2.11^{ \pm 0.11}$ \\
& 5 & $4.26^{ \pm 0.21}$ & $2.85^{ \pm 0.19}$ & $9.28^{ \pm 0.16}$ & $2.90^{ \pm 0.10}$ & $1.70^{ \pm 0.09}$ \\
& 7 & $4.83^{ \pm 0.24}$ & $2.18^{ \pm 0.16}$ & $9.81^{ \pm 0.18}$ & $2.04^{ \pm 0.10}$ & nd \\
& 14 & $4.50^{ \pm 0.23}$ & $2.23^{ \pm 0.16}$ & $9.32^{ \pm 0.17}$ & $2.95^{ \pm 0.10}$ & nd \\
& 30 & $5.00^{ \pm 0.25}$ & $2.58^{ \pm 0.18}$ & $9.16^{ \pm 0.12}$ & $2.80^{ \pm 0.09}$ & nd \\
\hline \multirow{4}{*}{ ME } & 1 & $3.78^{ \pm 0.19}$ & $2.90^{ \pm 0.15}$ & $9.96^{ \pm 0.10}$ & $2.74^{ \pm 0.09}$ & $1.98^{ \pm 0.10}$ \\
& 5 & $4.99^{ \pm 0.24}$ & $2.52^{ \pm 0.17}$ & $9.87^{ \pm 0.19}$ & $1.80^{ \pm 0.09}$ & $1.02^{ \pm 0.07}$ \\
& 7 & $5.00^{ \pm 0.25}$ & $2.48^{ \pm 0.18}$ & $10.8^{ \pm 0.12}$ & $1.63^{ \pm 0.09}$ & nd \\
& 14 & $5.12^{ \pm 0.25}$ & $2.20^{ \pm 0.16}$ & $10.71^{ \pm 0.10}$ & $1.26^{ \pm 0.08}$ & nd \\
& 30 & $5.21^{ \pm 0.26}$ & $2.85^{ \pm 0.14}$ & $10.78^{ \pm 0.17}$ & $1.00^{ \pm 0.05}$ & nd \\
\hline & 1 & $3.30^{ \pm 0.17}$ & $2.69^{ \pm 0.14}$ & $9.85^{ \pm 0.18}$ & $2.70^{ \pm 0.09}$ & $2.01^{ \pm 0.10}$ \\
& 5 & $4.22^{ \pm 0.21}$ & $2.20^{ \pm 0.16}$ & $9.42^{ \pm 0.17}$ & $1.84^{ \pm 0.12}$ & $1.00^{ \pm 0.09}$ \\
& 7 & $5.00^{ \pm 0.25}$ & $2.11^{ \pm 0.20}$ & $9.34^{ \pm 0.15}$ & $1.36^{ \pm 0.11}$ & nd \\
& 14 & $5.02^{ \pm 0.24}$ & $2.06^{ \pm 0.15}$ & $9.54^{ \pm 0.18}$ & $1.11^{ \pm 0.11}$ & nd \\
& 30 & $5.30^{ \pm 0.27}$ & $2.01^{ \pm 0.15}$ & $9.46^{ \pm 0.14}$ & $1.05^{ \pm 0.07}$ & nd \\
\hline
\end{tabular}

*Variation within treatments is not greater than $10 \%$ in all cases. 
662 Table 2. $\mathrm{pH}$, total acidity and lactose content of myzithra whey cheeses during

663 refrigerated $\left(4^{\circ} \mathrm{C}\right)$ storage for 30 days.

\begin{tabular}{ccccc}
\hline $\begin{array}{c}\text { myzithra } \\
\text { cheese }\end{array}$ & $\begin{array}{c}\text { Storage } \\
\text { time } \\
\text { (days) }\end{array}$ & $\mathrm{pH}$ & $\begin{array}{c}\text { Total acidity } \\
\text { (g lactic acid/ } \\
100 \mathrm{~g} \text { cheese })\end{array}$ & $\begin{array}{c}\text { Lactose } \\
(\mathrm{g} / 100 \text { g cheese })\end{array}$ \\
\hline \multirow{3}{*}{$\mathbf{C}$} & 1 & $6.47^{ \pm 0.04}$ & $0.19^{ \pm 0.01}$ & $3.78^{ \pm 0,08}$ \\
& 5 & $6.45^{ \pm 0.05}$ & $0.20^{ \pm 0.01}$ & $3.80^{ \pm 0,08}$ \\
& 7 & $6.47^{ \pm 0.05}$ & $0.20^{ \pm 0.01}$ & $3.79^{ \pm 0,07}$ \\
& 14 & $6.44^{ \pm 0.04}$ & $0.21^{ \pm 0.01}$ & $3.80^{ \pm 0,07}$ \\
& 30 & $6.43^{ \pm 0.04}$ & $0.21^{ \pm 0.01}$ & $3.78^{ \pm 0,04}$ \\
\hline $\mathbf{F}$ & 1 & $6.34^{ \pm 0.04}$ & $0.30^{ \pm 0.02}$ & $3.79^{ \pm 0,05}$ \\
& 5 & $6.22^{ \pm 0.03}$ & $0.38^{ \pm 0.02}$ & $3.66^{ \pm 0,06}$ \\
& 7 & $6.16^{ \pm 0.04}$ & $0.40^{ \pm 0.02}$ & $3.63^{ \pm 0,07}$ \\
$\mathbf{M E}$ & 14 & $6.08^{ \pm 0.04}$ & $0.48^{ \pm 0.03}$ & $3.60^{ \pm 0,06}$ \\
& 30 & $6.00^{ \pm 0.04}$ & $0.48^{ \pm 0.03}$ & $3.57^{ \pm 0,04}$ \\
\hline & 1 & $6.37^{ \pm 0.04}$ & $0.31^{ \pm 0.02}$ & $3.78^{ \pm 0,07}$ \\
& 5 & $6.17^{ \pm 0.04}$ & $0.50^{ \pm 0.03}$ & $3.67^{ \pm 0,06}$ \\
& 7 & $6.00^{ \pm 0.03}$ & $0.58^{ \pm 0.04}$ & $3.55^{ \pm 0,05}$ \\
& 14 & $5.94^{ \pm 0.03}$ & $0.60^{ \pm 0.04}$ & $3.53^{ \pm 0,07}$ \\
& 30 & $5.92^{ \pm 0.04}$ & $0.63^{ \pm 0.04}$ & $3.51^{ \pm 0,07}$ \\
\hline & 1 & $6.33^{ \pm 0.04}$ & $0.29^{ \pm 0.02}$ & $3.78^{ \pm 0,04}$ \\
& 5 & $6.19^{ \pm 0.04}$ & $0.28^{ \pm 0.02}$ & $3.67^{ \pm 0,04}$ \\
& 7 & $6.21^{ \pm 0.04}$ & $0.40^{ \pm 0.03}$ & $3.63^{ \pm 0,07}$ \\
& 14 & $6.04^{ \pm 0.03}$ & $0.44^{ \pm 0.03}$ & $3.61^{ \pm 0,06}$ \\
& 30 & $6.03^{ \pm 0.03}$ & $0.47^{ \pm 0.03}$ & $3.59^{ \pm 0,06}$ \\
\hline
\end{tabular}


665 Table 3. Terpenoid content (\%) of myzithra cheese samples (C, F, ME) from the $1^{\text {st }}$ day of 666 storage $\left(4^{\circ} \mathrm{C}\right)$ identified by SPME GC/MS.

\begin{tabular}{|c|c|c|c|c|c|c|}
\hline Compound name & ID* & KI & $\begin{array}{c}\text { KI from } \\
\text { literature }\end{array}$ & $\mathbf{C}$ & $\mathbf{F}$ & ME \\
\hline \multicolumn{7}{|l|}{ Monoterpens } \\
\hline$\alpha$-pinene & $\mathrm{KI}, \mathrm{MS}$ & 1025 & $\begin{array}{l}1017^{\mathrm{c}} \\
1020^{\mathrm{f}} \\
1019^{\mathrm{b}}\end{array}$ & $\mathrm{Nd}$ & $\mathrm{Nd}$ & $83.5^{ \pm 0.17}$ \\
\hline camphene & $\mathrm{KI}, \mathrm{MS}$ & 1063 & $\begin{array}{l}1053^{\mathrm{c}} \\
1080^{\mathrm{h}} \\
1063^{\mathrm{a}}\end{array}$ & $\mathrm{Nd}$ & $\mathrm{Nd}$ & $0.8^{ \pm 0.05}$ \\
\hline$\beta$-pinene & KI, MS & 1105 & $\begin{array}{l}1113^{\mathrm{d}} \\
1108^{\mathrm{b}}\end{array}$ & $\mathrm{Nd}$ & $\mathrm{Nd}$ & $2.2^{ \pm 0.13}$ \\
\hline 3-carene & KI, MS & 1138 & $\begin{array}{l}1114^{\mathrm{e}} \\
1141^{\mathrm{f}}\end{array}$ & $\mathrm{Nd}$ & $\mathrm{Nd}$ & $0.6^{ \pm 0.10}$ \\
\hline$\beta$-myrcene & KI, MS & 1152 & $\begin{array}{l}1157^{\mathrm{c}} \\
1152^{\mathrm{a}} \\
1158^{\mathrm{h}}\end{array}$ & $\mathrm{Nd}$ & $\mathrm{Nd}$ & $0.6^{ \pm 0.11}$ \\
\hline 2-carene & $\mathrm{KI}, \mathrm{MS}$ & 1164 & $1164^{\mathrm{a}}$ & $\mathrm{Nd}$ & $\mathrm{Nd}$ & $0.2^{ \pm 0.05}$ \\
\hline D-limonen & $\mathrm{KI}, \mathrm{MS}$ & 1180 & $1188^{\mathrm{e}}$ & $\mathrm{Nd}$ & $\mathrm{Nd}$ & $1.3^{ \pm 0.14}$ \\
\hline $\begin{array}{l}\text { Beta-phellandrene } \\
\text { o-cymene }\end{array}$ & $\begin{array}{l}\text { KI, MS } \\
\text { KI, MS }\end{array}$ & $\begin{array}{l}1188 \\
1250\end{array}$ & $\begin{array}{l}1188^{\mathrm{a}} \\
1250^{\mathrm{a}}\end{array}$ & $\begin{array}{l}\mathrm{Nd} \\
\mathrm{Nd}\end{array}$ & $\begin{array}{l}\mathrm{Nd} \\
\mathrm{Nd}\end{array}$ & $\begin{array}{l}0.1^{ \pm 0.03} \\
0.7^{ \pm 0.14}\end{array}$ \\
\hline
\end{tabular}

\section{Oxygenated Monoterpens}

\begin{tabular}{lllllll}
\hline Eucalyptol & KI, MS & 1196 & $1196^{\mathrm{a}}$ & $\mathrm{Nd}$ & $\mathrm{Nd}$ & $0.3^{ \pm 0.12}$ \\
Terpinolene & KI, MS & 1259 & $1271^{\mathrm{g}}$ & $\mathrm{Nd}$ & $\mathrm{Nd}$ & $3.5^{ \pm 0.13}$ \\
Camphelnol & KI, MS & 1482 & $1482^{\mathrm{a}}$ & $\mathrm{Nd}$ & $\mathrm{Nd}$ & $0.1^{ \pm 0.05}$ \\
Linalool & KI, MS & 1531 & $1531^{\mathrm{a}}$ & $\mathrm{Nd}$ & $\mathrm{Nd}$ & $0.2^{ \pm 0.05}$ \\
Bornyl acetate & KI, MS & 1571 & $1574^{\mathrm{g}}$ & $\mathrm{Nd}$ & $\mathrm{Nd}$ & $0.8^{ \pm 0.12}$ \\
4-terpineol & KI, MS & 1593 & $1602^{\mathrm{b}}$ & $\mathrm{Nd}$ & $\mathrm{Nd}$ & $0.3^{ \pm 0.14}$ \\
& & & $1593^{\mathrm{d}}$ & & & \\
Pinocarveol & KI, MS & 1651 & $1651^{\mathrm{a}}$ & $\mathrm{Nd}$ & $\mathrm{Nd}$ & $0.4^{ \pm 0.14}$ \\
Verbenol & KI, MS & 1671 & $1671^{\mathrm{a}}$ & $\mathrm{Nd}$ & $\mathrm{Nd}$ & $0.3^{ \pm 0.05}$ \\
a-terpineol & KI, MS & 1688 & $1691^{\mathrm{g}}$ & $\mathrm{Nd}$ & $\mathrm{Nd}$ & $1.3^{ \pm 0.12}$ \\
Melilotal & KI, MS & 1783 & $1783^{\mathrm{a}}$ & $\mathrm{Nd}$ & $\mathrm{Nd}$ & $0.2^{ \pm 0.03}$ \\
Myrtenol & KI, MS & 1787 & $1789^{\mathrm{g}}$ & $\mathrm{Nd}$ & $\mathrm{Nd}$ & $0.2^{ \pm 0.05}$ \\
p-cymene-8-ol & KI, MS & 1842 & $1846^{\mathrm{g}}$ & $\mathrm{Nd}$ & $\mathrm{Nd}$ & $0.7^{ \pm 0.13}$ \\
\hline
\end{tabular}

*ID: Method of identification, KI = tentative identification by Kovats retention index in accordance with literature [ ${ }^{a}$ : Schoina et al. (2014) ${ }^{b}:$ Shiratsuchi, Shimoda, Minegishi, and Osajima (1993), ${ }^{c}:$ Gardeli, Papageorgiou, Mallouchos, Kibouris, and Komaitis (2008), ${ }^{d}$ : Högnadóttir and Rouseff (2003), ${ }^{e}:$ Mallouchos, Paul, Bekatorou, Koutinas, and Komaitis (2007), ${ }^{f}$ : Vichi et al. (2007), ${ }^{g}$ : Lee, Umano, Shibamoto, and Lee (2005), ${ }^{h}$ : Goodner (2008)], MS = tentative identification by mass spectra obtained from NIST107, NIST21,

$674 * * *$ Variation within treatments is not greater than $10 \%$ in all cases. 


\section{Figure captions}

Figure 1. Electron micrographs of Pistacia terebinthus resin surface (A) and L. casei ATCC 393 cells in Pistacia terebinthus encapsulating matrix (B, C).

Figure 2. \% Survival of L. casei in myzithra cheeses during refrigerated storage $\left(4^{\circ} \mathrm{C}\right)$ for 30 days.

Figure 3. SPME GC-MS spectra (full scan mode chromatogram - A) presenting the detected terpenes (\% total area of hydrocarbons - B) of myzithra cheese with L. casei encapsulated cells within Pistacia terebinthus resin (ME) from the $1^{\text {st }}$ day of storage at $4^{\circ} \mathrm{C}$.

Figure 4. Sensory evaluation of produced myzithra chesses from the $1^{\text {st }}$ day of storage at $4^{\circ} \mathrm{C}$. 

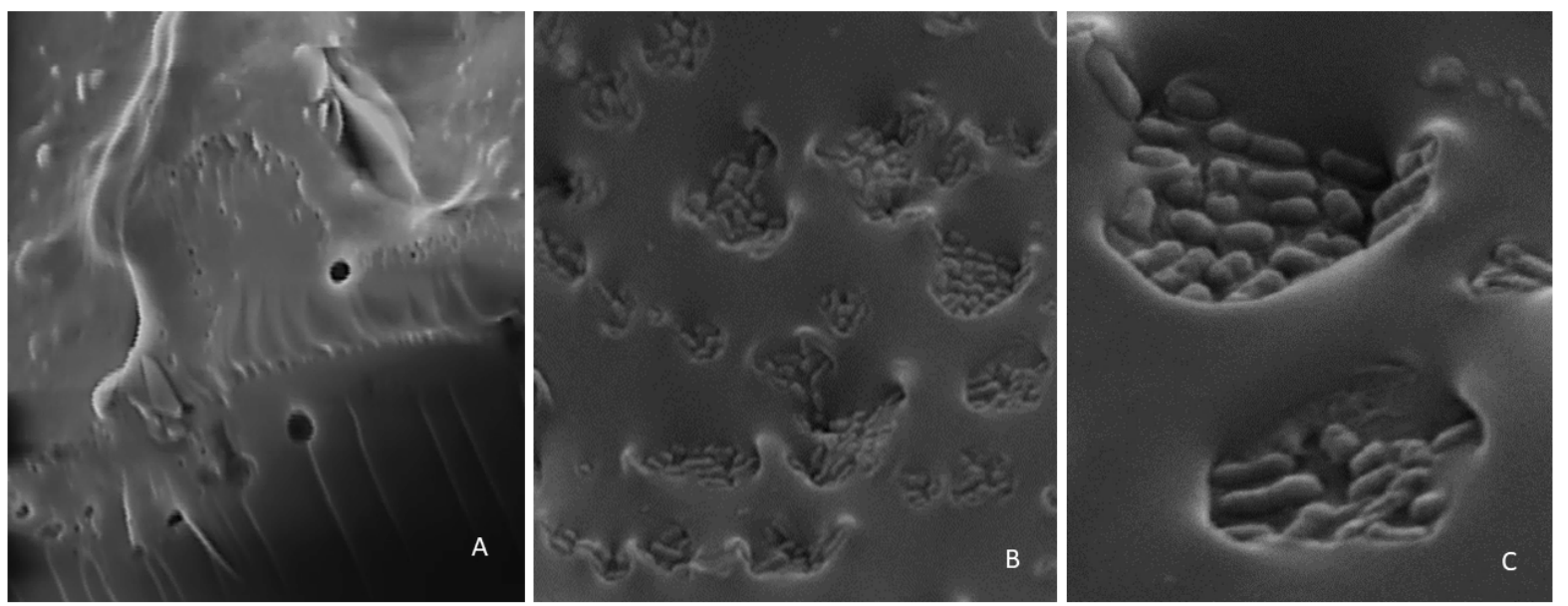


\section{ACCEPTED MANUSCRIPT}

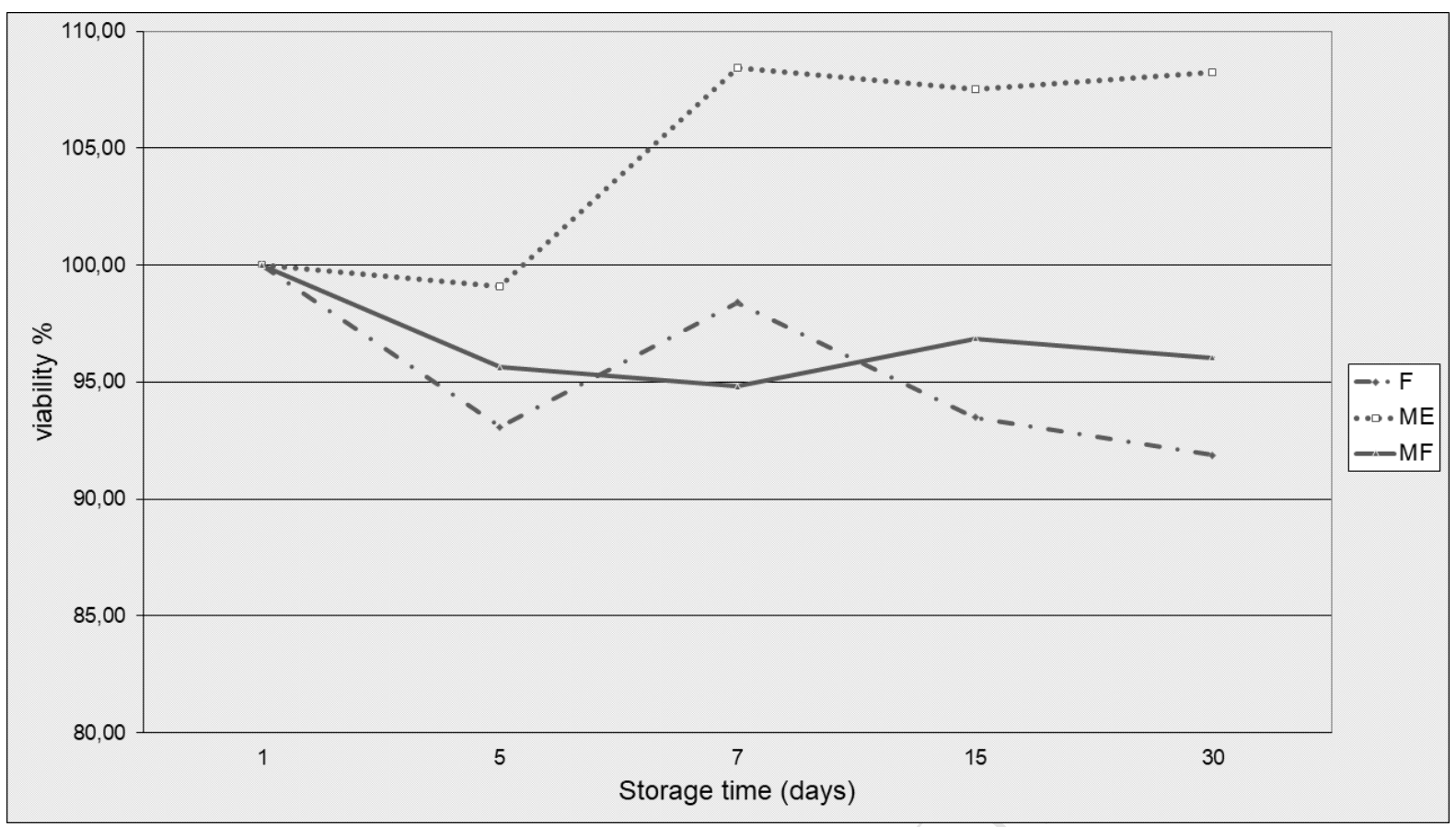




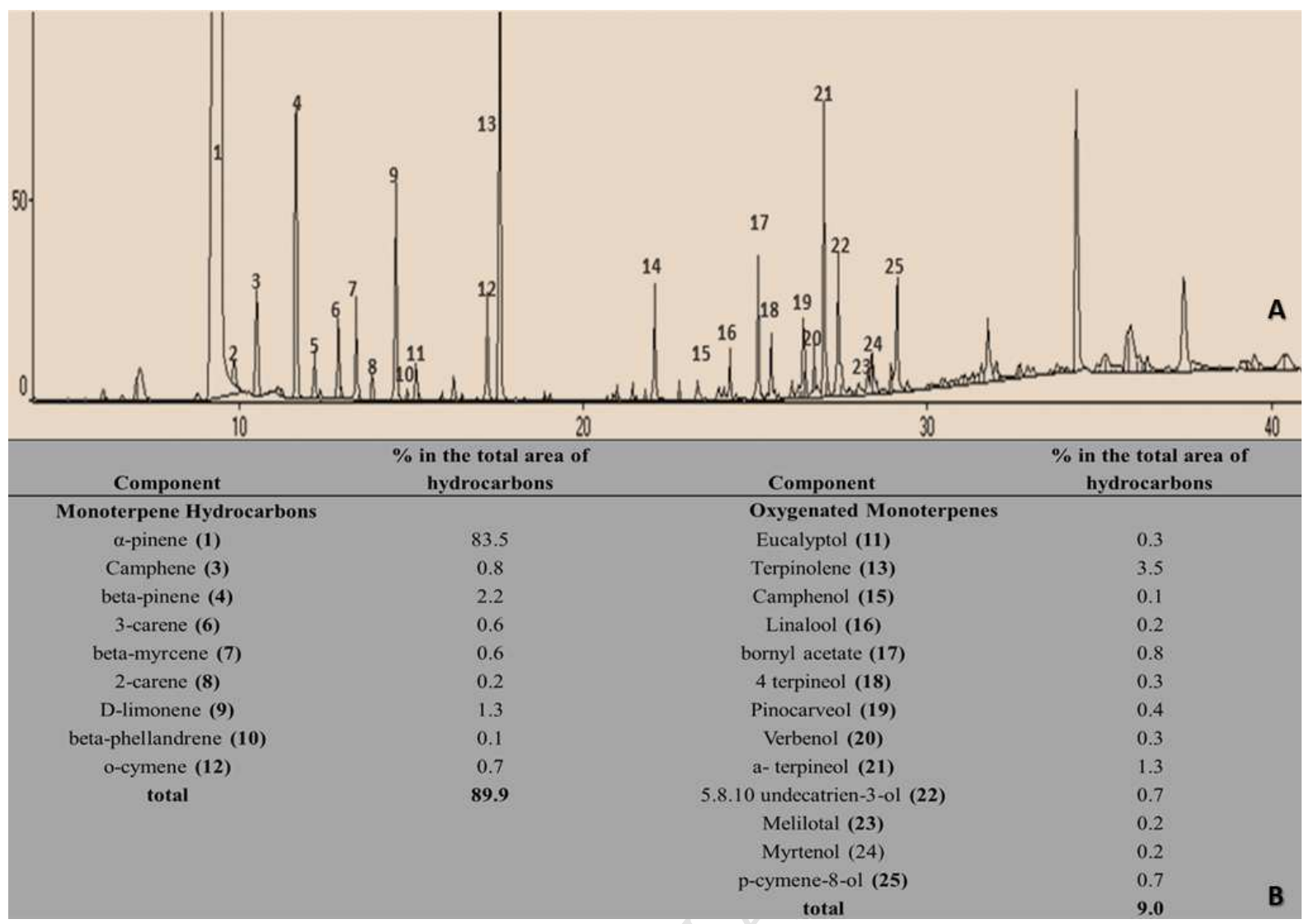




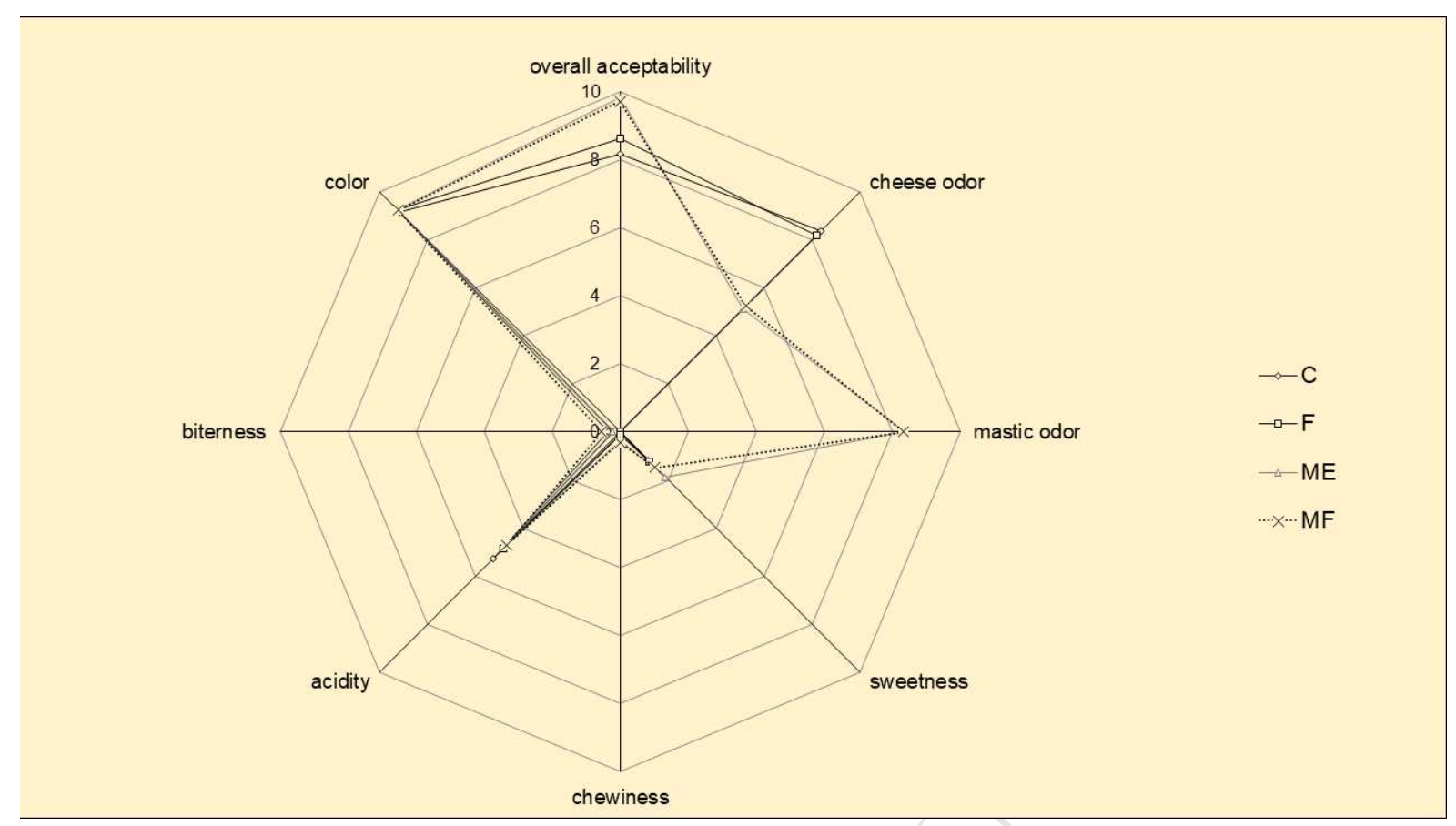




\section{Highlights}

- Manufacture of a novel functional myzithra cheese with probiotic characteristics.

- Pistacia terebinthus viscus matrix as encapsulation support of probiotic Lactobacillus cells.

- Significant reduction of fungi/yeasts in cheeses with incorporated Pistacia terebinthus resin.

- SPME GC/MS analysis indicates the upgraded terpenoid profile of cheeses with $P$. terebinthus resin.

- Terpene exceptional aroma and possible antimicrobial/ antioxidant effects to cheese products. 